\title{
Contamination and Health Risks of Certain Heavy Metals and Trace Elements in Milk and Milk Products Consumed in Province of Monufia, Egypt.
}

Mostafa, M.Abd Elgawad, ${ }^{1}$ Safaa M. Halawa ${ }^{1}$, Rania, M. Abdel Hamid ${ }^{2}$, Naglaa F. Abdel-Hameid ${ }^{1}$

${ }^{1}$ Plant Protection Department, Faculty of Agriculture, Benha University, Egypt

${ }^{2}$ Pesticides residues and environmental pollution department, central agricultural pesticides research central, Giza, Egypt.

\begin{abstract}
The objective of this study was to determine the residue levels of some heavy metals and heavy elements a total of 52 different random milk and cheese samples (16 samples of milk 4 raw and 12 of dairy milk purchased from local supermarkets in their original covers from 3 different company and (36 cheese samples (vita, olive and astamboly) purchased from local supermarkets from three different company in their original package collected from 9 towns inside the province of Monufia, Egypt. All examined samples were analyzed by Atomic Absorption Spectrophotometer to determine heavy metal residues and trace elements [lead $(\mathrm{Pb}), \mathrm{Cadmium}(\mathrm{Cd})$, Copper $(\mathrm{Cu})$, zinc $(\mathrm{Zn}), \mathrm{N} \mid \mathrm{ikal}(\mathrm{Ni})$ and manganese $(\mathrm{Mn})]$. and estimated the daily intake and health risk index. The highest trace metals accumulation levels for $\mathrm{Cd}$ are found in milk samples collected from factory A and B while not detected in factory $\mathrm{C}$, while samples from factory $\mathrm{A}, \mathrm{B}$ and $\mathrm{C}$ had high levels in $\mathrm{Pb}$ and $\mathrm{Mn}$. The most abundant element in all tested cheeses was $\mathrm{Zn}$, the richest content of $\mathrm{Zn}$ was identified in the three tested cheeses, the metal $\mathrm{Zn}$ in Olive cheese was $5.415,3.718$ and $4.16 \mathrm{mg} / \mathrm{kg}$ for factory A.B and C, respectively. The metal $\mathrm{Cd}$ not detected in all cheese tested. The THQ of all metals $(\mathrm{Cd}, \mathrm{Pb}, \mathrm{Cu}, \mathrm{Cr}, \mathrm{Ni}, \mathrm{Mn}$ and $\mathrm{Zn}$ ) via milk and dairy products consumption were less than one. The large variance and some high levels of contamination could be attributed to the application of quality standards in manufacturing and comparison with the other manufacturer.
\end{abstract}

Keywords: Milk, Cheese, Heavymetals, Trace elements Risk

\section{Introduction}

The toxicity of heavy metals to humans and animals is the result of exposure to long term and lower contamination in our environment, including in the air we breathe, water, food, and so on Ziarati $\boldsymbol{e t}$ al. (2012). In the last few years, the contamination of milk is considered as one of the main dangerous aspects. Trace metals are a general collective term applying to the group of metals and metalloids with an atomic density greater than $6 \mathrm{~g} / \mathrm{cm}$. This term is widely recognized and usually applied to the elements such as cadmium $(\mathrm{Cd}), \mathrm{Cu}$, Fe, lead $(\mathrm{Pb})$, and $\mathrm{Zn}$ which are commonly associated with pollution and toxicity problems (Malhatet al. 2012). Milk and dairy products are important components of the human diet. Milk has been described as a complete food because it contains vital nutrients including proteins, essential fatty acids, lactose, vitamins and minerals in balanced proportions. From the nutritional point of view, metals contents of milk and dairy products can be grouped into essential elements (iron, copper and zinc) at low doses and non-essential or toxic ones (lead and cadmium). The presence of the latter, even in low concentrations, is invaluable and leads to metabolic disorders with extremely serious consequences (Khan et al. 2008).

Milk as an excretion of the mammary gland can carry numerous xenobiotic substances, which constitute a technological risk factor for dairy products and above all, for the health of the consumer. Dairy animals ingest metals while grazing on the pasture and when fed on contaminated concentrate feeds. However, in the cow, the transfer of minerals to milk is highly variable (Maas $\boldsymbol{e t}$ al. 2011).Determination of the residual concentrations of metals in milk could be an important "direct indicator" of the hygienic status of the milk, as well as an "indirect indicator" of the degree of pollution of the environment in which the milk was produced (González-Montaña et al. 2012). In Egypt, pollution by heavy metals has increased due to anthropogenic activities such as agricultural projects, industrial and other activities along the Nile Delta (Darwish et al., 2015) .Egypt is an agricultural country, producing some of the finest quality food products but being a developing country facing issues in controlling the level of various contaminants especially heavy metals. Heavy metals accumulate in tissues of dairy animals and ultimately excrete in milk because of their non-biodegradable and persistent nature (Burger and Elbin, 2015). The bioaccumulation and transmission of heavy metal mixtures from water sources and feeding material have detrimental influences on milk pollution and cattle health which seem to be a serious issue affecting public health in those rural communities. The mechanism of the toxic action of lead can be explained by its ability to block sulfhydryl groups in enzymes involved in porphyrin synthesis (Schelkunov, et al. 2000). However,(Pigłowski 2018) reported that Cadmium is the most dangerous of heavy metals, with pronounced carcinogenic and mutagenic properties 
while, Lead is classified as a poison that primarily affects human nervous and vascular systems.

The presence of heavy metals and trace elements in milk and dairy products has been reported in different regions in Egypt, Meshref, et al. 2014 and Khalil, 2018 and in different countries, Sobhanardakani, 2018 and Sarsembayeva et al. 2020).To ensure the safety of milk and dairy products for the consumer, it is very important to know the heavy metals levels and compared with recommended toxicological criteria such as maximum residue limit (MRL) and the acceptable daily intake (ADI). Our study area is the Menoufia governorate which depends mainly on agriculture and livestock activities. Therefore, the present study was conducted to quantify the concentrations of heavy metals ( $\mathrm{Mn}, \mathrm{Ni}, \mathrm{Cr}, \mathrm{Pb}, \mathrm{Cu}, \mathrm{Zn}, \mathrm{Cd}, \mathrm{Mo}$ ) in milk and dairy products collected from 9 towns inside Menoufia Governorate, Egypt and estimated the daily intake and health risk index of them through consumption of milk and dairy products.

\section{Materials and Methods}

This research was carried out to determine contamination of raw fresh milk and some milk products, like, three different the kind of cheese by toxic heavy metals (Cadmium, $\mathrm{Cd}$ and Lead, $\mathrm{Pb}$ ) and trace metals (Copper $\mathrm{Cu}$, Manganese $\mathrm{Mg}$, Nickel NiChrome Cr, Cadmium Cd, and ZincZn) at Menoufia Province, Egypt during 2018.

\section{Collection and preparation of samples}

\subsection{Milk samples:}

Total of 16 samples of milk 4 raw were collected from several farms in Menoufia Province. The raw cow's milk samples $(500 \mathrm{ml}$ each) were collected from different supermarkets of 4 studied sites and kept in clean bottles. Samples were labelled to identify the source, site and date of sampling. Also, 12dairy milk was purchased from local supermarkets in their original covers from 3 different companies. All samples were kept in ice bags during their transportation to the Central of Agriculture Pesticides Laboratory, Giza, Egypt for analysis and stored at $20{ }^{\circ} \mathrm{C}$ until analysis

\subsection{Cheese samples:}

The 36 cheese samples (250 gm each) (vita, olive and astamboly) were purchased from local supermarkets from 3 different companies in their original package. Collected samples were stored in an ice-box and delivered to the Central of Agriculture Pesticides Laboratory, Giza, Egypt for analysis and stored at $-4^{\circ} \mathrm{C}$ until analysis.

\section{Sample preparation and Determination:}

Stock standard solutions heavy metals and trace metals of $\mathrm{Zn}, \mathrm{Cu}, \mathrm{Pb}, \mathrm{Fe}$ and $\mathrm{Cd}$ were obtained from Merck in a concentration of $1000 \mathrm{mg} / \mathrm{L}$ (Merck, Darmstadt, Germany. Nitric acid (HNO3) (density at $20^{\circ} \mathrm{C}: 1.4 \mathrm{~g} / \mathrm{mL}$ ) and (95\% purity) was obtained from SDS, Peypin, France.

\subsection{Determination of Heavy metals}

$1 \mathrm{gm}$ of cheese and $1 \mathrm{ml}$ of Milk samples were transferred in clean and acid washed screw capped digestion tubes. The samples were digested with nitric and perchloric acid mixture (HNO3-HCLO3, 4:1 v/v). After digestion, samples were filtered and diluted to $20 \mathrm{ml}$.

Quantitative determination was conducted by using thermo atomic absorption spectrometer model M5 equipped with a hollow cathode lamp and a deuterium background corrector, at respective wavelengths using an air-acetylene flame. Recoveries were carried out by the addition of the standards of each element at different levels. Blanks were included in each batch of analysis. Calibration standards were regularly performed to evaluate the accuracy of the analytical method. These and blank solutions were also analyzed in the same way as for the digested samples. Working calibration standards of zinc $(\mathrm{Zn})$, Nikal $(\mathrm{Ni})$, copper $(\mathrm{Cu})$, cadmium $(\mathrm{Cd})$ and lead $(\mathrm{Pb})$ were prepared by serial dilution of concentrated stock of $1000 \mathrm{mg} / \mathrm{L}$.

\section{1- Quality control:}

Quality control was assumed from the use of analytical blank and spike. The blanks were prepared similarly like the samples. All instrument readings were corrected with the blank. A recovery test of the entire procedure was carried out by a spike and analyzed with a known standard concentration of the metal of interest.

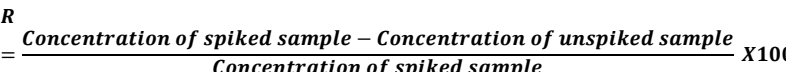
Concentration of spiked sample

\section{2-Estimated daily intake (EDI) of heavy metals}

The daily intake of heavy metals depends on the concentration of the residue in food and daily consumption. Besides, the body weight of the human can influence the tolerance of contaminates. The Estimated daily intake (EDI) of heavy metals was determined by the following equation:

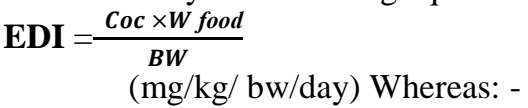

Coc $=$ is the concentration of heavy metals in contaminated foods. ( $\mathbf{m g} / \mathbf{k g})$

$\mathbf{W}$ weight food = food represents the daily intake food. $(\mathrm{kg})$

BW body weight $=$ represents the body averageweight.

The average daily consumption per adult person (70 $\mathrm{kg} \mathrm{BW}$ ) was considered to be $0.2 \mathrm{ml}$ and $0.022 \mathrm{gm}$ of milk and cheese, respectively.

\section{3- Target Hazard Quotient (THQ) (USEPA IRIS., 2012):}


For quantitative risk assessment, Target Hazard Quotient (THQ) was calculated as (the ratio of the potential exposure).

The hazard ratios were assessed by this equation:

THQ $=\frac{E D I}{\boldsymbol{R} F \boldsymbol{D}} \mathrm{mg} / \mathrm{kg} / \mathrm{day}$

Whereas:

$\mathbf{R F D}_{\mathbf{0}}=$ (reference dose of oral exposure) $(\mathrm{mg} / \mathrm{kg} /$ day) for each heavy metals and trace metals organochlorine.

A hazard ratio greater than one indicates that the milk or dairy products could be potential human health risk.

EDI = Estimated daily intake

\section{Statistical Analysishe}

The data was analyzed by using Excel data sheets and SPSS computer sotware version 17.the simple percentages plusmean values $+\mathrm{SD}$ of the heavy metals were calculated.

\section{Results and discussion.}

Leavels of heavy metal residues and health risk assessment in raw milk and some milk products

The concentration levels of the essential metals ( $\mathrm{Mn}, \mathrm{Ni}, \mathrm{Cr}, \mathrm{Cu}$ and $\mathrm{Zn}$ ) and the toxic metals $(\mathrm{Cd}$ and $\mathrm{Pb}$ ) in raw fresh milk and some milk products during the same period of year 2018 in Menoufia Province, Egypt are given in (Table 1). The results obtained that the values of trace elements in raw milk samples collected from different areas of the same seasons. Even the milk products have an influence on the values of heavy metals pollution. Raw milk detected higher levels in the samples of ( $\mathrm{Mn}, \mathrm{Ni}, \mathrm{Cr}, \mathrm{Cu}$ and $\mathrm{Zn}$ ) were $0.13,0.06,0.09,0.37$ and $0.19 \mathrm{mg} / \mathrm{kg}$, respectively and the toxic metals $(\mathrm{Cd}$ and $\mathrm{Pb}$ ) values were 0.04 and $0.33 \mathrm{mg} / \mathrm{kg}$ and no significant differences were observed in the samples of milk product which purchased from local supermarkets belonged to three factory A, B and C. The highest trace metals accumulation levels for $\mathrm{Cd}$ are found in milk samples collected from factory A and $\mathrm{B}$, respectively while not detected in factory $\mathrm{C}$ while samples from factory $\mathrm{A}, \mathrm{B}$ and $\mathrm{C}$ had high levels in $\mathrm{Pb}$ and $\mathrm{Mn}$, respectively. The large variance and some high levels of contamination could be attributed to the application of quality standards in manufacturing and comparison with the other manufacturer.Cadmium is the most dangerous of heavy metals, with pronounced carcinogenic and mutagenic properties (González et al. 2006) and Pigłowski, 2018). Also, Table (1) showed that the cadmium content in the milk samples varied from 0.04 to $0.003 \mathrm{mg} / \mathrm{kg}$, which did not exceed the maximum allowable concentration. Lead is classified as a poison that primarily affects human nervous and vascular systems. The mechanism of the toxic action of lead can be explained by its ability to block sulfhydryl groups in enzymes involved in porphyrin synthesis Schelkunov et al. (2000). The average values of Lead was higher than that of permissible maximum limit of $(0.05 \mathrm{mg} / \mathrm{kg})$ in the tested milk samples were $0.465,0.465$ and $0.43 \mathrm{mg} / \mathrm{l}$ from factory A, B and C) and was $0.325 \mathrm{mg} / \mathrm{l}$ with the row milk. The high concentration of $\mathrm{Pb}$ in milk might be explained by the Pollution of the environment with this metal. Lead alkyl additives into petrol are combusted and emitted into the atmosphere and can be responsible for high concentration of lead in some vegetation, roadside, soil, air, water and plant (Tunegovaet al., 2016, and Khalil 2018).

Levels of heavy metals in different kind of cheeses pouched from three Factories (A, B and C)

The heavy metals concentration in different milk products is shown in Tables $\mathbf{2 , 3}$ and 4). The results indicated that the concentration of total heavy metals in milk products are in the order of: Olive cheese $>$ Astamboly cheese >Vitacheese. All the heavy metals concentrations were several folds higher in the cheeses from Levels of heavy metals in cheeses from contaminated and reference Factories. The most abundant element in all tested cheeses was $\mathrm{Zn}$, the richest content of $\mathrm{Zn}$ was identified in the three tested cheeses, the metal $\mathrm{Zn}$ in Olive cheese was $5.415,3.718$ and $4.16 \mathrm{mg} / \mathrm{kg}$ for factory A.B and C, respectively (Table2). Zinc is an essential element for human health, it's important for normal growth and development in the human body. Literature reported wide variations in $\mathrm{Zn}$ concentration between studies, Nnadoziet al., 2014; Levkovet al., 2017 and Khalil, 2018). while, in the case of Astamboly cheese (Table 3) Zn concentration exceeds maximum allowable limit (MALs) in these kind of cheese. $\mathrm{LeadPb}$ are the most toxic heavy metals with very restrictive limits was detected also in Astamboly cheese in factory A, Band C was 2.623, 1.048 and $0.943 \mathrm{mg} / \mathrm{kg}$, respectively. The results in Tables (2, 3 and 4). showed that the metal $\mathrm{Cd}$ not detected in all cheese tested. While, the concentration of total heavy metals differed between different products, and factories, it was the higher concentration of average of metals in Factory Ain the three kind of cheese compared with the factory $\mathrm{B}$ and $\mathrm{C}$, the results are within the permissible limit.

\section{Daily metals intakes estimate and Target Hazard Quotients:}

Daily metals intakes estimate for each cheese are shown in Table (2,3 and 4). The dietary intakes of investigated metals, $\mathrm{Mn}, \mathrm{Ni}, \mathrm{Cr}, \mathrm{Cd}, \mathrm{Pb}, \mathrm{Cu}$, and $\mathrm{Zn}$ from cheeses in factory A, B and C were above the dietary intakes of metals from reference and below the tolerable limits. Also, Target hazard quotient (THQ) has been recognized as a useful parameter for evaluation of risks associated with the consumption of metal contaminated food (Zhuang, et al., 2009). 
Table 1. Heavy metal residues and health risk assessment in raw milk and some milk products during the same period of year 2018 in Menoufia Province (mg/kg):

\begin{tabular}{|c|c|c|c|c|c|c|c|c|c|c|c|c|c|c|c|}
\hline \multirow{3}{*}{$\begin{array}{l}\text { Name } \\
\text { of } \\
\text { Metal }\end{array}$} & \multirow{3}{*}{ Recovery } & \multirow{3}{*}{$\begin{array}{l}\text { RSD } \\
(\%)\end{array}$} & \multirow{2}{*}{\multicolumn{3}{|c|}{ Raw milk }} & \multicolumn{10}{|c|}{ Factories } \\
\hline & & & & & & \multicolumn{3}{|c|}{ Factory A } & \multicolumn{3}{|c|}{ Factory B } & \multicolumn{3}{|c|}{ Factory C } & \multirow[b]{2}{*}{ IDF } \\
\hline & & & $\begin{array}{l}(\operatorname{mean} \pm S E) \\
(\min -m a x .)\end{array}$ & EDI & THQ & $\begin{array}{l}\operatorname{mean} \pm \text { SE) } \\
(\text { min-max. })\end{array}$ & EDI & THQ & $\begin{array}{l}\text { mean } \pm \text { SE) } \\
(\min -m a x .)\end{array}$ & EDI & THQ & $\begin{array}{l}(\operatorname{mean} \pm S E) \\
(\min -m a x .)\end{array}$ & EDI & THQ & \\
\hline Mn & 85 & 6.8 & $\begin{array}{c}\mathbf{0 . 1 3 3} \pm 0.427 \\
0.01-0.2\end{array}$ & 0.0004 & 0.0027 & $\begin{array}{c}0.07 \pm 0.0349 \\
0.01-0.14\end{array}$ & 0.0002 & 0.0014 & $\begin{array}{c}0.118 \pm 0.036 \\
0.01-0.16\end{array}$ & 0.0003 & 0.0024 & $\begin{array}{c}0.093 \pm 0.0287 \\
0.01-0.14\end{array}$ & 0.0003 & 0.0019 & 0.025 \\
\hline $\mathrm{Ni}$ & 87 & 7.0 & $\begin{array}{c}0.06 \pm 0.0141 \\
0.04-0.1\end{array}$ & 0.0002 & 0.0086 & $\begin{array}{c}0.05 \pm 0.006 \\
0.04-0.06\end{array}$ & 0.0001 & 0.0071 & $\begin{array}{c}0.07 \pm 0.013 \\
0.04-0.1\end{array}$ & 0.0002 & 0.01 & $\begin{array}{c}0.058 \pm 0.0085 \\
0.04-0.08\end{array}$ & 0.0002 & 0.0082 & $1.0^{\mathrm{a}}$ \\
\hline $\mathrm{Cr}$ & 91 & 4.2 & $\begin{array}{c}0.097 \pm 0.0184 \\
0.05-0.14\end{array}$ & 0.0003 & 0.093 & $\begin{array}{c}0.059 \pm 0.0312 \\
0.008-0.14\end{array}$ & 0.0002 & 0.0567 & $\begin{array}{c}0.073 \pm 0.021 \\
0.01-0.1\end{array}$ & 0.0002 & 0.069 & $\begin{array}{c}\mathbf{0 . 0 7 8} \pm \mathbf{0 . 0 2 9} \\
0.01-0.14\end{array}$ & 0.0002 & 0.069 & $0.3^{\mathrm{a}}$ \\
\hline Cd & 98 & 8.3 & $\begin{array}{c}0.04 \pm 0.04 \\
0-0.16\end{array}$ & 0.0001 & 0.114 & $\begin{array}{c}0.003 \pm 0.003 \\
0-0.01\end{array}$ & 0.00001 & 0.0086 & $\begin{array}{c}0.003 \pm 0.003 \\
0-0.01\end{array}$ & 0.00001 & 0.0086 & ND & ND & ND & $0.026^{b}$ \\
\hline $\mathbf{P b}$ & 93 & 5.7 & $\begin{array}{c}0.325 \pm 0.0974 \\
0.04-0.48\end{array}$ & 0.0009 & 0.2654 & $\begin{array}{c}0.465 \pm 0.127 \\
0.14-0.76\end{array}$ & 0.0013 & 0.3797 & $\begin{array}{c}0.465 \pm 0.105 \\
0.14-0.66\end{array}$ & 0.0012 & 0.3511 & $\begin{array}{c}0.43 \pm 0.075 \\
0.04-0.38\end{array}$ & 0.0007 & 0.212 & $0.05^{\mathrm{b}}$ \\
\hline $\mathrm{Cu}$ & 95 & 5.2 & $\begin{array}{c}0.37 \pm 0.0332 \\
0.28-0.42\end{array}$ & 0.001 & 0.0285 & $\begin{array}{c}0.205 \pm 0.061 \\
0.02-0.28\end{array}$ & 0.0006 & 0.0158 & $\begin{array}{c}0.205 \pm 0.083 \\
0.02-0.32\end{array}$ & 0.0005 & 0.0127 & $\begin{array}{c}0.165 \pm 0.063 \\
0.02-0.3\end{array}$ & 0.0006 & 0.0189 & $0.1^{\mathrm{b}}$ \\
\hline $\mathbf{Z n}$ & 91 & 4.2 & $\begin{array}{c}\mathbf{0 . 1 8 5} \pm 0.025 \\
0.16-0.26\end{array}$ & 0.0005 & 0.0018 & $\begin{array}{c}1.47 \pm 0.4165 \\
0.26-2.02\end{array}$ & 0.0042 & 0.014 & $\begin{array}{c}1.47 \pm 0.003 \\
0.2-0.21\end{array}$ & 0.0006 & 0.002 & $\begin{array}{c}0.205 \pm 0.017 \\
0.12-0.12\end{array}$ & 0.0004 & 0.0014 & $3.28^{b}$ \\
\hline
\end{tabular}

ND: Not Detected

EDI : Estimated daily intake \% Rec:Average Recoveries \%

RSD (\%): Relative Standard Deviation percentage. $\quad$ THQ : Target Hazard Quotient

IDF: International Dairy Federation Standard, a 1977 and b 1979. 
Table 2. Estimated daily intake, THQ for daily intake of heavy metal residues through consumption of vita cheese (mg/kg) in Menoufia Province (mg/kg):

\begin{tabular}{|c|c|c|c|c|c|c|c|c|c|c|c|c|}
\hline \multirow{3}{*}{$\begin{array}{l}\text { Name of } \\
\text { Metal }\end{array}$} & \multirow{3}{*}{$\begin{array}{c}\text { Recovery } \\
\%\end{array}$} & \multirow{3}{*}{$\begin{array}{c}\text { RSD } \\
(\%)\end{array}$} & \multicolumn{9}{|c|}{ Factories } & \multirow[b]{3}{*}{ IDF } \\
\hline & & & \multicolumn{3}{|c|}{ Factory A } & \multicolumn{3}{|c|}{ Factory B } & \multicolumn{3}{|c|}{ Factory C } & \\
\hline & & & $\begin{array}{l}(\operatorname{mean} \pm \mathrm{SE}) \\
(\min -\mathrm{max} .)\end{array}$ & 0.025 & THQ & $\begin{array}{c}(\operatorname{mean} \pm S E) \\
(\min -m a x .)\end{array}$ & EDI & THQ & $\begin{array}{c}\text { mean } \pm \text { SE) } \\
(\min -\max .)\end{array}$ & EDI & THQ & \\
\hline Mn & 89 & 9.0 & $\begin{array}{c}0.359 \pm 0.034 \\
0.32-0.48\end{array}$ & $1.0^{\mathrm{a}}$ & 0.0008 & $\begin{array}{c}0.213 \pm 0.061 \\
0.13-0.39\end{array}$ & 0.0001 & 0.0007 & $\begin{array}{c}0.14 \pm 0.04 \\
0.1-0.26\end{array}$ & 0.00004 & 0.0003 & 0.025 \\
\hline $\mathbf{N i}$ & 85 & 4.5 & $\begin{array}{c}0.125 \pm 0.059 \\
0.06-0.3\end{array}$ & $0.3^{\mathrm{a}}$ & 0.002 & $\begin{array}{c}0.255 \pm 0.112 \\
0.2-0.48\end{array}$ & 0.0001 & 0.005 & $\begin{array}{c}0.068 \pm 0.018 \\
0.05-0.12\end{array}$ & 0.00002 & 0.001 & $1.0^{\mathrm{a}}$ \\
\hline $\mathrm{Cr}$ & 84 & 5.1 & $\begin{array}{c}\mathbf{0 . 1 4 3} \pm 0.010 \\
0.13-0.17\end{array}$ & & 0.0133 & $\begin{array}{c}0.258 \pm 0.161 \\
0.08-0.74\end{array}$ & 0.0001 & 0.0333 & $\begin{array}{c}0.143 \pm 0.022 \\
0.1-0.2\end{array}$ & 0.00004 & 0.0133 & $0.3^{\mathrm{a}}$ \\
\hline Cd & 95 & 4.8 & ND & $0.05^{b}$ & ND & ND & ND & ND & ND & ND & ND & $0.026^{b}$ \\
\hline $\mathbf{P b}$ & 89 & 4.3 & $\begin{array}{c}1.395 \pm 0.147 \\
0.96-1.6\end{array}$ & $0.1^{b}$ & 0.1143 & $\begin{array}{c}1.398 \pm 0.091 \\
1.25-1.65\end{array}$ & 0.0004 & 0.1143 & $\begin{array}{c}0.848 \pm 0.082 \\
0.62-1\end{array}$ & 0.0003 & 0.0857 & $0.05^{b}$ \\
\hline $\mathbf{C u}$ & 94 & 6.7 & $\begin{array}{c}0.443 \pm 0.636 \\
0.26-0.55 \\
\end{array}$ & $3.28^{b}$ & 0.0027 & $\begin{array}{c}\mathbf{0 . 5 3 3} \pm \mathbf{0 . 0 8 7} \\
\mathbf{0 . 3 7 - 0 . 7 7} \\
\end{array}$ & 0.0002 & 0.0054 & $\begin{array}{c}0.403 \pm 0.019 \\
0.35-0.44 \\
\end{array}$ & 0.0001 & 0.0027 & $0.1^{b}$ \\
\hline Zn & 88 & 8.2 & $\begin{array}{c}5.415 \pm 0.744 \\
3.2-6.29 \\
\end{array}$ & IDF & 0.0057 & $\begin{array}{c}3.718 \pm 0.283 \\
3.28-4.51 \\
\end{array}$ & 0.0012 & 0.004 & $\begin{array}{c}4.16 \pm 0.561 \\
2.52-5.05 \\
\end{array}$ & 0.0013 & 0.0043 & $3.28^{b}$ \\
\hline
\end{tabular}

ND: Not Detected EDI : Est 0.0057 $\quad 3.28-4.51$

RSD (\%): Relative Standard Deviation percentage. THQ : Target Hazard Quotient

IDF: International Dairy Federation Standard, a 1977 and b 1979. 
Table 3. Estimated daily intake, THQ for daily intake of heavy metal residues through consumption of Astamboly cheese (mg/kg) in Menoufia Province (mg/kg)

\begin{tabular}{|c|c|c|c|c|c|c|c|c|c|c|}
\hline \multirow{3}{*}{ Name of Metal } & \multicolumn{9}{|l|}{ Factories } & \multirow{3}{*}{ IDF } \\
\hline & \multicolumn{3}{|c|}{ Factory A } & \multicolumn{3}{|c|}{ Factory B } & \multicolumn{3}{|c|}{ Factory C } & \\
\hline & $\begin{array}{c}(\text { mean } \pm \text { SE }) \\
(\min -m a x .)\end{array}$ & EDI & THQ & $\begin{array}{c}\text { mean+SE) } \\
\text { (min-max.) }\end{array}$ & EDI & THQ & $\begin{array}{c}\text { mean } \pm \text { SE) }(\text { min- } \\
\text { max. })\end{array}$ & EDI & THQ & \\
\hline Mn & $\begin{array}{c}0.473 \pm 0.108 \\
0.28-0.78\end{array}$ & 0.0001 & 0.0007 & $\begin{array}{c}0.22 \pm 0.080 \\
0.12-0.46\end{array}$ & 0.0001 & 0.0007 & $\begin{array}{c}0.208 \pm 0.083 \\
0.02-0.37\end{array}$ & 0.0001 & 0.0007 & 0.025 \\
\hline $\mathbf{N i}$ & $\begin{array}{l}0.1 \pm 0.041 \\
0.04-0.22\end{array}$ & 0.00003 & 0.0015 & $\begin{array}{c}0.093 \pm 0.063 \\
0.02-0.28\end{array}$ & 0.00003 & 0.0015 & $\begin{array}{c}0.148 \pm 0.058 \\
0.05-0.3\end{array}$ & 0.00005 & 0.0025 & $1.0^{\mathrm{a}}$ \\
\hline $\mathrm{Cr}$ & $\begin{array}{c}4.673 \pm 2.672 \\
0.11-10.4\end{array}$ & 0.0015 & 0.5 & $\begin{array}{c}0.183 \pm 0.057 \\
0.07-0.3\end{array}$ & 0.0001 & 0.0333 & $\begin{array}{c}0.123 \pm 0.013 \\
0.1-0.15\end{array}$ & 0.00004 & 0.0133 & $0.3^{\mathrm{a}}$ \\
\hline Cd & ND & ND & ND & ND & ND & ND & ND & ND & ND & $0.026^{b}$ \\
\hline $\mathbf{P b}$ & $\begin{array}{c}2.623 \pm 1.124 \\
0.98-6.31\end{array}$ & 0.0008 & 0.2286 & $\begin{array}{c}1.048 \pm 0.053 \\
0.95-1.17\end{array}$ & 0.0003 & 0.0857 & $\begin{array}{c}0.943 \pm 0.136 \\
0.57-1.22\end{array}$ & 0.0003 & 0.0857 & $0.05^{b}$ \\
\hline $\mathrm{Cu}$ & $\begin{array}{c}0.9 \pm 0.188 \\
0.57-1.3\end{array}$ & 0.0003 & 0.0081 & $\begin{array}{c}0.973 \pm 0.353 \\
0.42-1.92\end{array}$ & 0.0003 & 0.0081 & $\begin{array}{c}0.56 \pm 0.044 \\
0.47-0.65\end{array}$ & 0.0002 & 0.0054 & $0.1^{b}$ \\
\hline $\mathbf{Z n}$ & $\begin{array}{c}5.748 \pm 0.795 \\
3.41-6.9 \\
\end{array}$ & 0.0018 & 0.006 & $\begin{array}{c}3.993 \pm 0.545 \\
3.22-5.6 \\
\end{array}$ & 0.0013 & 0.0043 & $\begin{array}{c}4.213 \pm 0.686 \\
2.82-5.55 \\
\end{array}$ & 0.0013 & 0.0043 & $3.28^{b}$ \\
\hline
\end{tabular}

ND: Not Detected

EDI : Estimated daily intake \% Rec:Average Recoveries \%

RSD (\%): Relative Standard Deviation percentage. THQ : Target Hazard Quotient

IDF: International Dairy Federation Standard, a 1977 and b 1979. 
Table 4. Estimated daily intake, THQ for daily intake of heavy metal residues through consumption of olive cheese (mg/kg) in Menoufia Province (mg/kg):

\begin{tabular}{|c|c|c|c|c|c|c|c|c|c|c|}
\hline \multirow{3}{*}{$\begin{array}{l}\text { Name of } \\
\text { Metal }\end{array}$} & \multicolumn{9}{|c|}{ Factories } & \multirow{3}{*}{ IDF } \\
\hline & \multicolumn{3}{|c|}{ Factory A } & \multicolumn{3}{|c|}{ Factory B } & \multicolumn{3}{|c|}{ Factory C } & \\
\hline & $\begin{array}{l}(\text { mean } \pm \text { SE) } \\
(\text { Min-max.) }\end{array}$ & EDI & THQ & $\begin{array}{c}\text { mean } \pm \text { SE) } \\
(\text { min-max.) }\end{array}$ & EDI & THQ & $\begin{array}{c}\text { mean } \pm \text { SE) } \\
(\text { min-max.) }\end{array}$ & EDI & THQ & \\
\hline Mn & $\begin{array}{c}0.383 \pm 0.020 \\
0.35-0.44\end{array}$ & 0.00012 & 0.0009 & $\begin{array}{c}0.215 \pm 0.051 \\
0.1-0.34\end{array}$ & 0.0007 & 0.005 & $\begin{array}{c}0.528 \pm 0.258 \\
0.22-1.3\end{array}$ & 0.0002 & 0.0014 & 0.025 \\
\hline $\mathbf{N i}$ & $\begin{array}{c}0.258 \pm 0.071 \\
0.11-0.42\end{array}$ & 0.0001 & 0.005 & $\begin{array}{c}0.313 \pm 0.224 \\
0.05-0.98\end{array}$ & 0.0001 & 0.005 & $\begin{array}{c}0.108 \pm 0.022 \\
0.05-0.15\end{array}$ & 0.00003 & 0.0015 & $1.0^{\mathrm{a}}$ \\
\hline $\mathrm{Cr}$ & $\begin{array}{c}0.128 \pm 0.018 \\
0.11-0.18\end{array}$ & 0.00004 & 0.0133 & $\begin{array}{c}0.938 \pm 0.795 \\
0.07-3.32\end{array}$ & 0.0003 & 0.1 & $\begin{array}{c}0.148 \pm 0.009 \\
0.13-0.17\end{array}$ & 0.00005 & 0.0167 & $0.3^{\mathrm{a}}$ \\
\hline Cd & ND & ND & ND & ND & ND & ND & ND & ND & ND & $0.026^{b}$ \\
\hline $\mathbf{P b}$ & $\begin{array}{c}1.35 \pm 0.160 \\
0.88-1.6\end{array}$ & 0.00042 & 0.12 & $\begin{array}{c}0.91 \pm 0.078 \\
0.27-1.07\end{array}$ & 0.0003 & 0.0857 & $\begin{array}{c}1.088 \pm 0.142 \\
0.77-1.42\end{array}$ & 0.0003 & 0.0857 & $0.05^{b}$ \\
\hline $\mathbf{C u}$ & $\begin{array}{c}0.563 \pm 0.036 \\
0.5-0.66\end{array}$ & 0.0002 & 0.0054 & $\begin{array}{c}0.768 \pm 0.380 \\
0.3-1.9\end{array}$ & 0.0002 & 0.0054 & $\begin{array}{c}0.753 \pm 0.103 \\
0.55-1.02\end{array}$ & 0.0002 & 0.0054 & $0.1^{b}$ \\
\hline Zn & $\begin{array}{l}5.7 \pm 0.031 \\
4.94-6.49\end{array}$ & 0.0018 & 0.006 & $\begin{array}{c}4 \pm 0.668 \\
2.8-5.8\end{array}$ & 0.0013 & 0.0043 & $\begin{array}{c}5.295 \pm 1.598 \\
3.15-10.02\end{array}$ & 0.0017 & 0.0057 & $3.28^{b}$ \\
\hline
\end{tabular}

RSD (\%): Relative Standard Deviation percentage. $\quad$ THQ: Target Hazard Quotient

IDF: International Dairy Federation Standard, a 1977 and b 1979 
From the foregoing results, it could be concluded that the heavy metals concentrations in row milk and milk products manufactured at Province of Monufia are in permissible limit according to Egyptian Organization for Standardization and Quality Control (EOS, 2012) and IDF Standard (1977 and 1979). The THQ of all metals $(\mathrm{Cd}, \mathrm{Pb}, \mathrm{Cu}, \mathrm{Cr}, \mathrm{Ni}, \mathrm{Mn}$ and $\mathrm{Zn}$ ) via milk and dairy products consumption were less than one. These values suggesting that the inhabitants in Province of Monufia will not be exposed to a potential health risk from consumption of milk and dairy products, but still they have the potential to result in serious problems as other dietary and non>dietary factors also contribute in the calculation for total daily intake of heavy metals. Though, it cannot be concluded that there was no risk for human health. It is seemly necessary to warn about the hazardous effects of these toxic elements on adult. these result agree with (Khalil,2018 and Abdelfatahet al. 2019)

\section{Conclusion}

From all previously results showed that the examined different random milk and cheese samples (16 samples of milk 4 raw and 12 of dairy milk and dairy products which purchased from local supermarkets in their original covers from 3 different company were contaminated with heavy metal residues with variable amounts, but these amounts were exceeded through manufacturing, packaging and several stages. Heavy metals residues in milk could be controlled by monitoring of water and feed for livestock as well as application of appropriate containers in transit of raw milks may be helpful for production of healthier milks. Strict and regular monitoring of heavy metal residues of imported milk and milk products at different ports and that which above the permissible limits should be refused and return to the original factory.

\section{Reference}

Abdelfatah, Mohamed,Eman N.;Mansour,A. H.; Ahmed,Nagwa I.;El-Ganzory,Hussein $H$. (2019): Heavy metal residues and health risk assessment in raw milk and dairy products with a trail for removal of copper residues. Benha veterinary medical journal, vol. 36, no. 1:51-64,

Burger Asw, J. and Elbin, S. ( 2015) : Metal levels in eggs of waterbirds in the New York Harbor (USA): Trophic relationships and possible risk to human consumers. J. Toxicol. Environ. Health A. 78, 78-91

Darwish, W.S.; Hussein, M.A.; El-Desoky, K.I; Ikenaka, Y.; Nakayama, S., Mizukawa, H. and Ishizuka, M. (2015): Incidence and public health risk assessment of toxic metal residues (cadmium and lead) in Egyptian cattle and sheep meats. Int. Food Res. J., 22(4): 1719-1726.

Egyptian Standard(2012): Egyptian Organization for Standardization and QualityControl. Maximum level of heavy metals contaminant in food in food.ES 2360, Ministry of Industry. Cairo, Egypt.

González-Weller, D.; Karlsson, L.; Caballero, A.; Hernández, F.; Gutiérrez, A. and GonzálezIglesias, T.(2006): Lead and cadmium in meat and meat products consumed by the population in Tenerife Island, Spain. FoodAddit. Contam., 23(8): 757-763.

International dairy federation (IDF) standard (1977): Metal contaminations in milk and milk products. Int ernational Diary Federation Bulletin. Document No. A. Doe. 37

International dairy federation (IDF) standard (1979): Metal contamination in milk and milk products. International Dairy Federation Bulletin. Document no. A. Doe 37

Khalil, O. S. F. (2018): Risk Assessment of Certain Heavy Metals and Trace Elements in Milk and Mil k Products Consumed in Aswan Province. J. Food and Dairy Sci., Mansoura Univ., Vol. 9 (8): 289 - 296, 2018

Khan, S; Cao, Q.; Zheng,Y.M.; Huang,Y.Z. and Zhu, Y.G. (2008): Health risks of heavy metals in contaminated soils and food crops irrigated with wastewater in Beijing, China. Environ. Pollut. 152,686-692 (2008)

Levkov, V.; Stafilov, T.; Pacinovski, N.; Baciva, K.;Mateva, N.gjorgovska N.;Eftimova E., and Kostadinov, T. ( 2017): Content of major and trace elements in raw ewes' milk used for production of traditional white brined cheese. Slovak. J. Anim., Sci.,50 (1): 7 - 14.

Maas, S.; Lucot, E.; Gimbert, F.; Crini, N. and Badot, P. M. (2011): Trace metals in raw cows' milk and assessment of transfer to Comté cheese. Food chemistry, 129(1), 7-12.

Malhat, F., Hagag, M. and Saber, A. (2012):Contamination of cow's milk byheavy metal in Egypt. Bulletin of environmental contamination and toxicology, 88(4), 611-613.

Meshref, A. M.; Moselhy, W. A.; and Hassan, N. E. H. Y. (2014) : Heavy metals and trace elements levels in milk and milk products. Journal of food measurement and characterization, 8(4), 381-388.

Nnadozi, C.U.;Birnin Yauri, U.A. and Muhmmad, C. (2014). Assessment of some dairy products sold in Sokoto Metropolis, Nigeria. Int. J. Advanc. Resh. In Chemical Sci.,1(10):31>37.

Pigłowski, M. (2018) Heavy metals in notifications of rapid alert system for food and feed. Int. J. Environ. Res. Public Health, 15(2): 365.

Sarsembayeva N. B. ;Abdigaliyeva, T. B.;UtepovaZ. A. ;Biltebay, A. N. and ,S. Zh. 
(2020):Heavy metal levels in milk and fermented milk products produced in the Almaty region, Kazakhstan. Veterinary World vol 13: 609-613.

Schelkunov, L.F.; Dudkin, M.S. and Korzun, V.N. (2000):PishchaiEkologiya [Food and Environmental Protection], Odessa, Optimum.Addit. Contam., 23(8): 757-763.22

Sobhanardakani, Soheil (2017): Human Health Risk Assessment of $\mathrm{Cd}, \mathrm{Cu}, \mathrm{Pb}$ and $\mathrm{Zn}$ through Consumption of Raw and Pasteurized Cow's Milk * Iran J Public Health, Vol. 47, No.8, Aug 2018, pp.1172-1180.

Tunegova, M.; Toman, R. and Tancin,V. (2016): Hevy metals environmental contaminants and their occurrence in different types of milk. Slovak J. Anim. Sci., 49,(3):122-131.
USEPA IRIS. (2012): United States Environmental Protection Agency Integrated Risk Information System Human Health Risk Assessment. Risk Based Screening Table (Accessed 21.04.13.)

Zhuang, P.; McBride, M.B.; Xia, H.; Li, N. and Li, Z. (2009): Health risk from heavymetals via consumption of food crops in the vicinity of Dabaoshan mine, south China.Journal of the Science of the Total Environment, 407(5):15511561

Ziarati, Parisa; Moghimi, Saba; Arbabi-Bidgoli, Sepideh and Qomi, Mahnaz (2012) : Risk Assessment of Heavy Metal Contents (Lead and Cadmium) in Lipsticks in Iran. International Journal of Chemical Engineering and Applications, Vol. 3, No. 6, December 2012 
التلوث والمخاطر الصحية لبعض المعادن الثقيلة والعناصر الثقيلة والنادرة في الحليب ومنتجات الألبان المستهلكة في محافظة المنوفية ، مصر . مداف

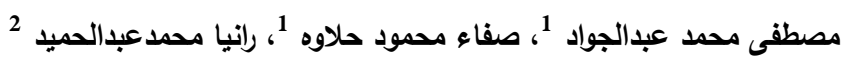

و نجلاء فكرى عبدالحميد 1 أناء

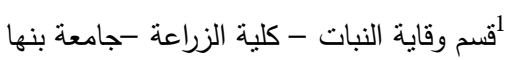

2قفم بحوث منتقيات المبيدات وتلوث البيئة،المعمل المركز يللمبيدات ،مركزالبحوث الزراعية، جيزة،مصر.

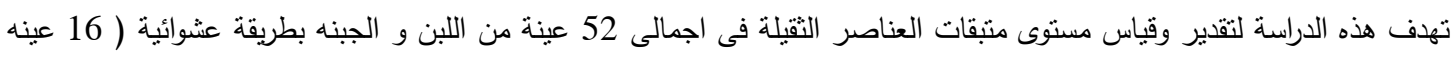

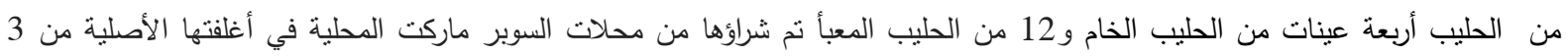

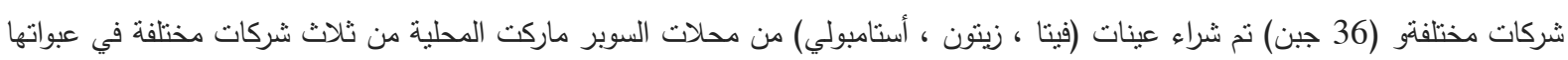

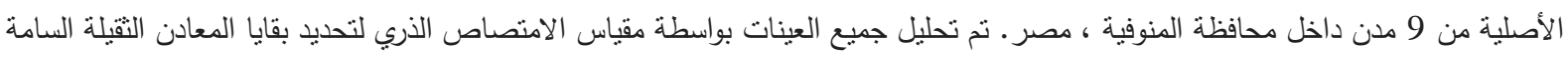

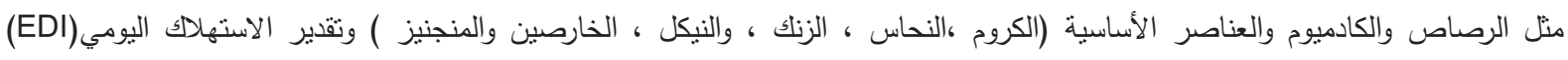

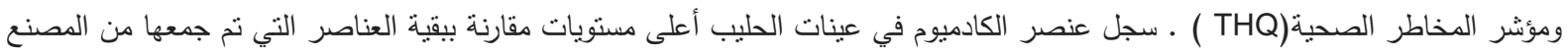

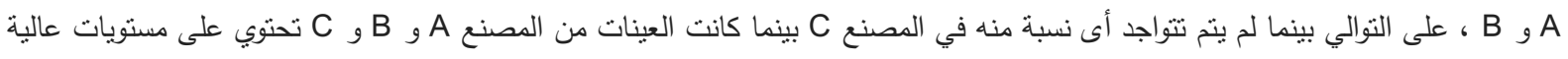

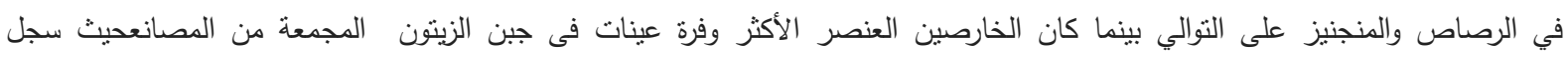

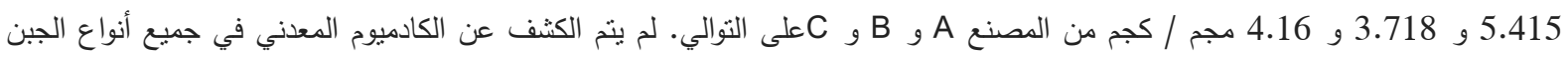

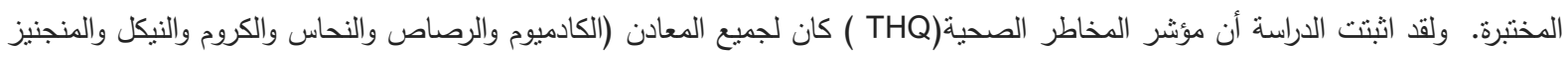

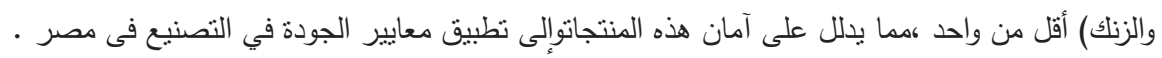

